\title{
Heterogeneous Predisposing Factors and Etiology of Edema of the Uvula in a Spanish Population
}

\author{
Barbarroja-Escudero J', Asúnsolo-Del-Barco A², Sánchez-González MJ1', Rodríguez-Rodríguez M1', \\ Alvarez-Mon $\mathrm{M}^{1}$
}

'Servicio de Enfermedades del Sistema Inmune-Alergia, Hospital Universitario Príncipe de Asturias, Departamento de Medicina y Especialidades Médicas, Facultad de Medicina y Ciencias de la Salud, Universidad de Alcalá, Alcalá de Henares, Madrid, Spain

${ }^{2}$ Department of Surgery, Medical and Social Sciences, University of Alcala, Alcalá de Henares, Madrid, Spain

J Investig Allergol Clin Immunol 2019; Vol. 29(4): 280-286

doi: 10.18176/jiaci.0324

\begin{abstract}
Background: Edema of the uvula (EU) may appear in isolation or in association with clinical manifestations such as urticaria, angioedema, and anaphylaxis. EU may lead to upper airway obstruction, provoking obstructive respiratory distress and asphyxia.

Objective: We sought to investigate the etiology of and predisposing factors for EU in a large population of patients referred to an outpatient clinic.

Methods: In this 3-year follow-up cohort study, 171 patients presenting with EU were identified and classified as having isolated EU or nonisolated EU. The etiology of each patient's condition was studied, and possible predisposing factors were recorded. An allergology work-up and a statistical study (bivariate/multivariate analyses) were performed.

Results: The predisposing factors for both groups of EU patients were found to be different. The etiology of the problem was identified for most patients; allergy to Anisakis simplex was the most common cause in both groups. Nonsteroidal anti-inflammatory drugs and antibiotics were also found to be triggers in both groups.

Conclusions: Isolated EU was associated with snoring, an elongated uvula, and having experienced previous episodes of EU. We found no associations between groups of EU patients and gender, obesity, smoking, alcohol consumption, personal and family history of atopy, and obstructive sleep apnea. Allergy to A simplex was the most commonly recorded cause.
\end{abstract}

Key words: Allergy. Anisakis simplex. Elongated uvula. Obesity. Smoking. Snoring. Uvula edema.

\section{Resumen}

Introducción: El edema de úvula (EU) puede aparecer aislado o en asociación con otras manifestaciones clínicas, tales como urticaria, angioedema o anafilaxia. En cualquier caso, puede provocar una obstrucción de la vía aérea superior que a veces puede ser grave. Objetivo: Intentamos investigar la etiología y los factores predisponentes del EU de una gran población de pacientes derivados a nuestras consultas.

Métodos: En este estudio de cohortes de 3 años de seguimiento, se valoraron 171 pacientes que presentaban EU, clasificándose como EU aislado o EU no aislado. Se estudió la etiología de la condición clínica de cada paciente y se registraron los posibles factores predisponentes en cada caso, a través de un estudio alergológico y estadístico, con el fin de comprobar una asociación significativa entre ellos.

Resultados: Se encontró que los factores predisponentes para ambos grupos de pacientes eran diferentes. Una etiología fue identificada para la mayoría de los casos, siendo la alergia a Anisakis simplex la causa más común para ambos grupos. Los fármacos antiinflamatorios no esteroideos y los antibióticos también fueron identificados como etiologías para ambos grupos.

Conclusiones: Encontramos que el EU aislado se asoció con roncopatía, úvula elongada y haber sufrido episodios previos de EU. No se demostró asociación entre ambos grupos de pacientes con el sexo, obesidad, tabaquismo, hábito enólico, atopia personal y familiar 0 apnea obstructiva del sueño. La alergia a A. simplex fue la causa más frecuentemente demostrada.

Palabras clave: Alergia. Anisakis simplex. Úvula elongada. Obesidad. Tabaquismo. Roncopatía. Edema de úvula. 


\section{Introduction}

The uvula is a muscular organ whose function includes the secretion of thin saliva and the sealing of the pharynx during speech and swallowing $[1,2]$. Edema of the uvula (EU) is an entity with no defined, established, or standardized diagnostic criteria. Its diagnosis is based on clinical features. EU can provoke obstructive respiratory distress and asphyxia [1-3]. It may appear in isolation (EU with no associated clinical manifestations, isolated EU) $[3,4]$ or in association with other manifestations such as urticaria, angioedema at other locations, asthma, and anaphylaxis (EU with associated clinical manifestations) $[5,6]$.

EU can be a presenting complaint in the emergency department and in the allergy department and, as such, could be of interest for physicians working in these areas. Therefore, the aim of the present observational study was to characterize and compare the predisposing factors and etiology of both isolated EU and EU with associated clinical manifestations in a large cohort of patients referred to an outpatient clinic.

\section{Materials and Methods}

\section{Study Population and Data Collection Protocol}

This prospective longitudinal cohort study was approved by the Ethics Review Board of University Hospital of Alcalá de Henares, Madrid, Spain. The participants comprised 171 consecutive patients with a diagnosis of EU (with and without associated clinical manifestations) who attended our Clinical Immunology and Allergy Outpatient Department between April 2009 and September 2013. Most (around $90 \%$ ) were referred by the staff of the emergency department at our hospital; the remainder were referred by their general practitioners. At the first visit, a direct visual examination of the uvula was made, a questionnaire with emphasis on personal and family angioedema and atopy events was completed, and a detailed clinical interview was held on the use of concomitant medications and possible predisposing factors and etiologies [5]. An allergology work-up was also performed.

Skin prick tests (SPTs) were carried out (Roxall Laboratories) with a broad panel of common food- and airborne allergens and a negative control (50\% glycerinated saline) and positive control (histamine, $10 \mathrm{mg} / \mathrm{mL}$ ) [7]. When a positive outcome was clinically relevant, a patient-based, tailored strategy based on step-by-step planning was implemented. In fact, prick-prick testing (PPT) was carried out with specific foods (fresh or cooked foods) according to the patient's clinical history [8]. SPT and PPT results were considered positive when the wheal was $\geq 3 \mathrm{~mm}$ greater than the negative control [7]. Although airborne allergens are never involved in angioedema, we performed the tests in all patients in order to confirm/rule out an atopic background. Blood was also taken for a complete blood count and for general biochemical analysis, as well as to determine the erythrocyte sedimentation rate and to examine the thyroid hormone profile (including antithyroid antibodies), antinuclear antibodies, C-reactive protein, complement levels (C3, C4, and C1 inhibitor), hydatidosis serology, serum baseline tryptase levels, serum total IgE, and serum specific
IgE levels after skin testing with common food- and airborne allergens. Serum total IgE, specific IgE, and baseline tryptase levels were measured using ImmunoCAP (Thermo Fisher). Allergy to Anisakis was established in all cases by means of SPT, serum specific IgE levels, and after performing oral food challenges with fish and/or cephalopods following anti-Anisakis conditions (frozen at $-20^{\circ} \mathrm{C}$ for at least 48 hours) [9]. Food and drug allergies were determined based on a convincing medical history, skin tests (SPT and PPT to foods; SPT and intradermal tests to drugs), specific IgE testing, and/or challenge tests, as previously described $[7,8,10]$. The diagnosis of allergy to antibiotics and nonsteroidal antiinflammatory drugs (NSAIDs) was made following established procedures $[7,8,10]$. Of note, there is no specific test to assess acquired angioedema related to angiotensin-converting enzyme inhibitors (ACEI)/angiotensin II receptor antagonists (ARA-II) (bradykinin-mediated angioedema). This entity was diagnosed following established criteria [11]. Once the results were obtained, the patients returned for a diagnostic visit. Furthermore, each patient was followed up over a 3-year-period in order to assess any change in diagnosis.

The patients were classified as having either EU without associated clinical manifestations (isolated EU) or EU with associated clinical manifestations, as previously described [4,5]. These manifestations included urticaria, angioedema at other locations, asthma, and anaphylaxis with/ without hypotension [4-6]. The latter group were referred to as "nonisolated EU patients" (EU with associated clinical manifestations). Following this study protocol, the etiology of each patient's condition was then assessed, and possible predisposing factors recorded. Predisposing factors were defined as personal behaviors, environmental exposures, or inborn or inherited characteristics associated with an increased occurrence of EU. Etiology or causative factors were defined as events or behaviors that directly influence the onset of EU [12]. Patients were considered to be smokers if they smoked at least 1 cigarette, pipe, or cigar per day, exsmokers if they had completely stopped consumption of all types of tobacco at least 6 months before the first visit, and nonsmokers if they had never smoked [13]. We classified the patients according to Mediterranean alcohol-drinking patterns as follows: low intake (women $<5 \mathrm{~g} / \mathrm{d}$, men $<10 \mathrm{~g} / \mathrm{d}$ ), moderate intake (women $5-25 \mathrm{~g} / \mathrm{d}$, men 10-50 g/d), and high intake (women $>25 \mathrm{~g} / \mathrm{d}$, men $>50 \mathrm{~g} / \mathrm{d}$ ) [14]. Lifetime abstainers were defined as people who have never consumed alcohol [15]. Heavy episodic drinking as defined as $\geq 60 \mathrm{~g}$ of alcohol on $\geq 1$ occasion at least monthly [15]. Patients with a body mass index (BMI) of $>30 \mathrm{~kg} / \mathrm{m}^{2}$ and $26-30 \mathrm{~kg} / \mathrm{m}^{2}$ were described as obese and overweight, respectively [16]. Those with a BMI of $20-25 \mathrm{~kg} / \mathrm{m}^{2}$ were considered to have a healthy weight [16]. Obstructive sleep apnea (OSA) was clinically defined by the occurrence of daytime sleepiness, loud snoring, witnessed breathing interruptions, or awakenings due to gasping or choking in the presence of at least 5 obstructive respiratory events (apnea, hypopnea, or respiratory effort-related arousals) per hour of sleep in the polysomnogram [17]. Snoring was defined as a rough rattling noise made on inspiration during sleep by vibration of the soft palate and the uvula [18]. Atopy was defined as a state of clinical hypersensitivity or allergy 
with a hereditary predisposition or the inherited tendency to develop allergy [19]. The number of previous EU events was also recorded for each patient. We also included some medical conditions hitherto described in previous studies as etiologies of EU, such as upper respiratory tract infection, pharyngoesophageal reflux, hereditary angioedema with FXII mutation (FXII-HAE), and tonsillectomy [5,20,21], as well as others not reported to date (antibiotics, pollen immunotherapy, hymenoptera venom, and cancer).

\section{Statistical Analysis}

Quantitative variables were expressed as mean (SD) for normally distributed data or as median (IQR) for nonnormally distributed data. Categorical variables were expressed using absolute and relative frequencies. Comparisons between continuous variables were made using the $t$ test or the MannWhitney test, as appropriate. Categorical qualitative variables were compared using the Pearson $\chi^{2}$ test or the Fisher exact test. Multiple, stepwise, forward logistic regression (in, $P$ value $<.05$; out, $P$ value $<.1$ ) was performed using factors that proved to be significant in the bivariate and multivariate analyses to examine the association between predisposing factors/etiologies and isolated/nonisolated EU. The results were presented as the odds ratio (OR) and 95\% confidence intervals $(95 \% \mathrm{CI})$. All calculations were performed using SPSS 20.0 software (IBM Corp). A $P$ value less than .05 was considered statistically significant.

\section{Results}

\section{Patient Characteristics}

Mean age was 47 (17) years (range, 13-91 years), and $65.5 \%$ of patients were men. Isolated EU was recorded in 113 patients $(66.1 \%)$ and nonisolated EU in 58 patients $(33.9 \%)$. Table 1 shows the main descriptive data for the patient sample.

\section{Patients Diagnosed With Isolated EU and Patients Diagnosed With Nonisolated EU Show Different Predisposing Factors}

The most commonly recorded predisposing factors for EU as a whole were snoring (107 patients, 62.6\%), personal atopy (75 patients, $43.9 \%$ ), and being a smoker (72 patients, $42.1 \%$ ) (Table 1).

Differences were seen, however, in the predisposing factors for isolated EU and nonisolated EU. The percentage of smokers, alcohol consumers (with no health risk), and snorers was significantly higher (more than double) in the isolated EU group than in the nonisolated EU group, and the former had 4 times as many patients with an elongated uvula and nearly 4 times as many with a history of previous (or recurrent) EU. Ten patients in the isolated EU group and none in the nonisolated EU group had OSA syndrome (Table 1). Of note, both the patients with suspected OSA syndrome and the snorers were referred to the Pulmonology and ENT Departments to make the definitive diagnosis before being included. In both departments, an overlapping or confounding disease was also ruled out in both groups.
Table 1. Demographic Characteristics, Predisposing Factors, and Etiology in Patients Diagnosed With EU

\begin{tabular}{|c|c|c|}
\hline Parameters & $\begin{array}{c}\text { Isolated } \\
\text { EU }\end{array}$ & $\begin{array}{c}\text { Nonisolated } \\
\text { EU }\end{array}$ \\
\hline Total patients $(\mathrm{N}=171)$, No. $(\%)$ & $113(66.1)$ & $58(33.9)$ \\
\hline Male sex, No. (\%) & $77(68.1)$ & $35(60.3)$ \\
\hline Mean (SD) age, y & $46(16)$ & $48(18)$ \\
\hline $\begin{array}{l}\text { Tobacco consumption, No. (\%) } \\
\text { Nonsmokers } \\
\text { Smokers } \\
\text { Ex-smokers }\end{array}$ & $\begin{array}{l}46(40.7) \\
54(47.8) \\
13(11.5)\end{array}$ & $\begin{array}{l}27(46.6) \\
18(31) \\
13(22.4)\end{array}$ \\
\hline $\begin{array}{l}\text { Alcohol intake, No. (\%) } \\
\text { Lifetime abstainer } \\
\text { Low } \\
\text { Moderate } \\
\text { High }\end{array}$ & $\begin{array}{c}76(67.3) \\
24(21.2) \\
10(8.8) \\
3(2.7)\end{array}$ & $\begin{array}{l}48(82.8) \\
7(12.1) \\
2(3.4) \\
1(1.7)\end{array}$ \\
\hline $\begin{array}{l}\text { BMI class, } \mathrm{kg} / \mathrm{m}^{2}, \text { No. }(\%) \\
\text { Obese }(>30) \\
\text { Overweight }(26-30) \\
\text { Healthy }(20-25)\end{array}$ & $\begin{array}{l}36(31.9) \\
38(33.6) \\
39(34.5)\end{array}$ & $\begin{array}{l}16(27.6) \\
21(36.2) \\
20(34.5)\end{array}$ \\
\hline Snorers, No. (\%) & $82(72.6)$ & $25(43.1)$ \\
\hline OSA syndrome, No. (\%) & $10(8.8)$ & 0 \\
\hline Elongated uvula, No. (\%) & $45(39.8)$ & $7(12.1)$ \\
\hline Personal atopy, No. (\%) & $49(43.4)$ & $26(44.8)$ \\
\hline Family atopy, No. (\%) & $27(23.9)$ & $11(19)$ \\
\hline $\begin{array}{l}\text { Patients with previous/ } \\
\text { recurrent episodes, No. }(\%)^{\mathrm{a}}\end{array}$ & $77(68.1)$ & $20(34.5)$ \\
\hline $\begin{array}{l}\text { Etiology, No. }(\%) \\
\text { Foods } \\
\text { Drugs } \\
\text { Medical conditions } \\
\text { Idiopathic }\end{array}$ & $\begin{array}{l}37(32.7) \\
20(17.7) \\
28(24.8) \\
28(24.8)\end{array}$ & $\begin{array}{l}26(44.8) \\
18(31) \\
4(6.9) \\
10(17.2)\end{array}$ \\
\hline
\end{tabular}

Abbreviations: EU, edema of the uvula; OSA, obstructive sleep apnea. aPrevious/recurrent episodes refers to patients who had experienced previous episodes of EU before a definitive diagnosis was established during the diagnostic visit.

Multiple logistic regression analysis confirmed that patients with isolated EU reported snoring significantly more often $(\mathrm{OR}, 3.45 ; 95 \% \mathrm{CI}, 1.80-6.78)$ and that significantly more had experienced previous (or recurrent) episodes of EU (OR, 4.06; 95\%CI, 2.08-7.95) than patients with nonisolated EU. Furthermore, significantly more had an elongated uvula (OR, $4.82 ; 95 \%$ CI, 2.00-11.57). Differences for medical conditions did not reach statistical significance $(P=.05)$ (Table 2$)$.

\section{The Causative Factors of Isolated EU and Nonisolated EU Were Similar}

The cause of EU was determined in 133 patients (77.8\%). Overall, the most common cause was food-associated allergy (total 63 patients: 37 patients diagnosed with isolated EU [58.7\%], 26 patients diagnosed with EU with other manifestations [41.3\%], nonsignificant), followed by 
Table 2. Logistic Regression Analysis of the Predisposing Factors and Etiology in Patients Diagnosed with EU

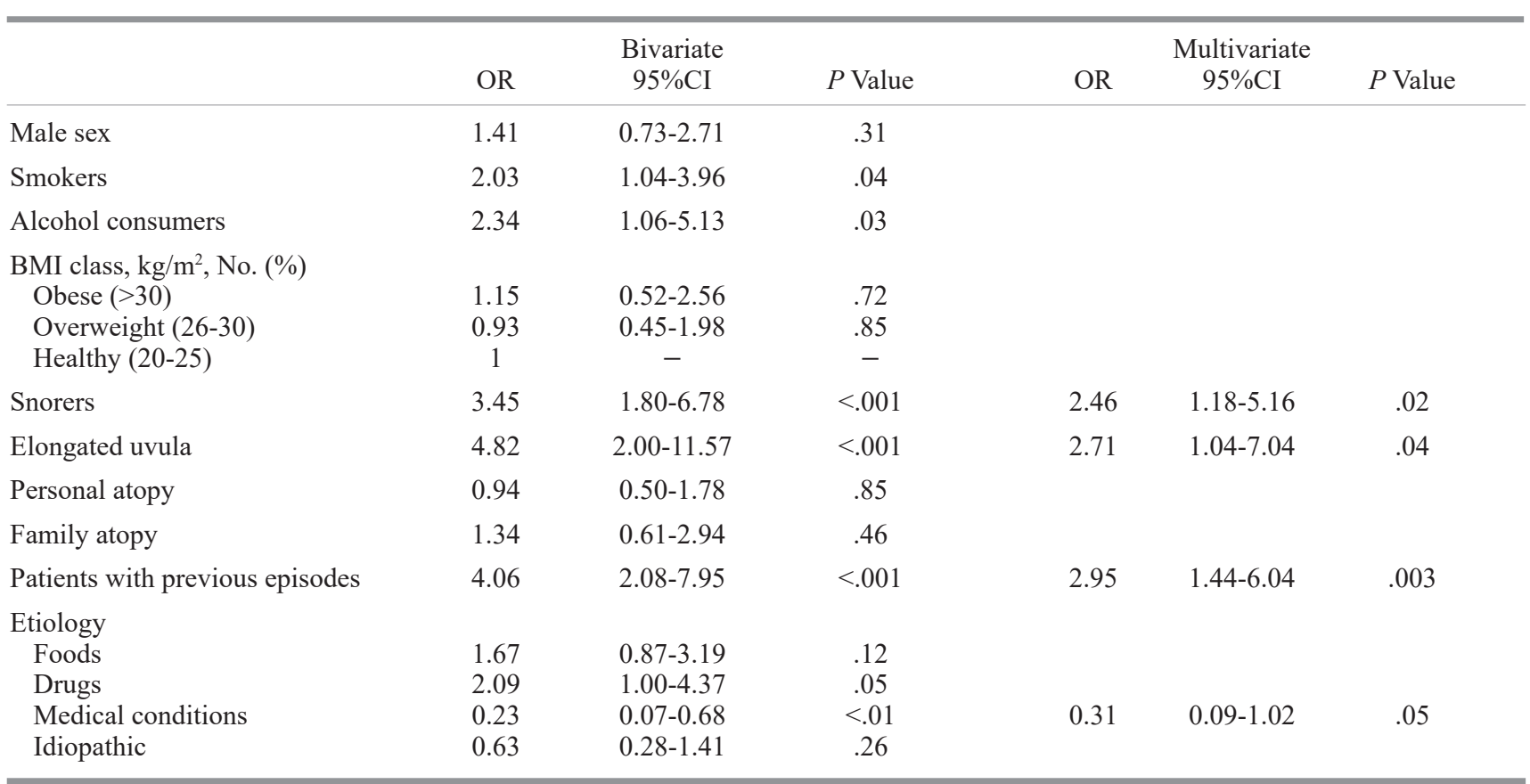

Abbreviations: EU, edema of the uvula; BMI, body mass index.

reaction to drugs (total 38 patients: 20 patients diagnosed with isolated EU [52.6\%], 18 patients diagnosed with nonisolated EU [47.4\%], nonsignificant) and idiopathic causes (total 38 patients: 28 patients diagnosed with isolated EU $[73.7 \%], 10$ patients diagnosed with nonisolated EU [26.3\%], nonsignificant). However, a significant difference was seen between the isolated EU group and the nonisolated EU group with respect to associated medical conditions (total 32 patients: 28 patients diagnosed with isolated EU [87.5\%], 4 patients diagnosed with nonisolated EU [12.5\%]; $P=.02$ ) (Table 3).

The most commonly detected food-associated EU-causing agents were Anisakis simplex (total 35 patients: 23 patients diagnosed with isolated EU [65.4\%], 12 patients diagnosed with nonisolated EU [34.3\%], nonsignificant), lipid transfer protein (total 19 patients: 9 patients diagnosed with isolated EU [47.4\%], 10 patients diagnosed with nonisolated EU [52.6\%], nonsignificant), and shellfish (total 9 patients: 5 patients diagnosed with isolated EU [55.6\%], 4 patients diagnosed with nonisolated EU [44.4\%], nonsignificant) (Table 3). Patients with Anisakis allergy had a mean specific IgE titer of 7.42 (12.82) kU/L (range, 0.38-58.70). Another 4 patients were Anisakis-sensitive (IgE levels of $0.40,0.68,0.70$, and $1.02 \mathrm{kU} / \mathrm{L}$ ). During the 3 years following the present study, these 4 patients had further EU episodes despite following the anti-Anisakis conditions mentioned above [9], suggesting that Anisakis was not the cause of their EU episode(s).

Drug-induced EU was the second most common etiology (38 patients, $22.2 \%$ ) (Table 3 ). The most frequently involved drugs were ibuprofen (total 10 patients: 5 patients diagnosed with isolated EU [50.0\%], 5 patients diagnosed with nonisolated EU [50.0\%], nonsignificant), amoxicillin (total 8 patients: 2 patients diagnosed with isolated EU [25.0\%], 6 patients diagnosed with nonisolated EU [75.0\%], nonsignificant), and ACE inhibitors/ARA-II (total 7 patients: 6 patients diagnosed with isolated EU [85.7\%], 1 patient diagnosed with nonisolated EU [14.3\%], nonsignificant). One patient diagnosed with nonisolated EU caused by enalapril also presented with labial edema.

The medical conditions most commonly associated with EU—in particular isolated EU — appeared to be heavy episodic drinking (total 16 patients: 16 patients diagnosed with isolated EU [100\%], 0 patients diagnosed with nonisolated EU [0.0\%]; $P<.001$ ) and upper respiratory tract infection (total 7 patients: 7 patients diagnosed with isolated EU [100\%], 0 patients diagnosed with nonisolated EU [0.0\%], nonsignificant) (Table 3). However, logistic regression analysis ruled out any significant association with either $(P=.05)$ (Table 2$)$.

Differences for the other variables analyzed, in particular serum total IgE and baseline tryptase levels and complement study, were nonsignificant and did not appear to be causative agents or associated with isolated EU or nonisolated EU (Table 4).

\section{Discussion}

We describe a large cohort of Spanish patients diagnosed with EU. Our results show that the predisposing factors for isolated EU differ from those that predispose to nonisolated EU, namely, patients with isolated EU were more often snorers, had an elongated uvula, and had more commonly experienced previous episodes of EU. We found no associations between groups of EU patients and gender, obesity, smoking, alcohol consumption, personal and family atopy, and OSA. The etiology of the condition was identified in most patients; allergy to $A$ simplex was the most common etiology both in patients with isolated EU and in those with nonisolated EU. 
Table 3. Etiology of Isolated EU and Nonisolated EU

\begin{tabular}{|c|c|c|c|}
\hline $\begin{array}{l}\text { Causative factor, } \\
\text { No. }(\%)\end{array}$ & $\begin{array}{c}\text { Total } \\
\text { EU } \\
(\mathrm{N}=171)\end{array}$ & $\begin{array}{c}\text { Isolated } \\
\text { EU } \\
(n=113)\end{array}$ & $\begin{array}{c}\text { Nonisolated } \\
\text { EU } \\
(\mathrm{n}=58)\end{array}$ \\
\hline Foods & $63(36.8)$ & $37(58.7)$ & $26(41.3)$ \\
\hline Anisakis & $35(20.5)$ & $23(65.4)$ & $12(34.3)$ \\
\hline Lipid transfer protein & $19(11.1)$ & $9(47.4)$ & $10(52.6)$ \\
\hline Shellfish & $9(5.3)$ & $5(55.6)$ & $4(44.4)$ \\
\hline Drugs & $38(22.2)$ & $20(52.6)$ & $18(47.4)$ \\
\hline NSAIDs & $15(8.8)$ & $7(46.7)$ & $8(53.3)$ \\
\hline Ibuprofen & $10(5.8)$ & $5(50)$ & $5(50)$ \\
\hline Dexketoprofen & $2(1.2)$ & $1(50)$ & $1(50)$ \\
\hline Aspirin & $2(1.2)$ & $1(50)$ & $1(50)$ \\
\hline Metamizole & $1(0.6)$ & - & $1(100)$ \\
\hline Antibiotics & $12(7)$ & $4(33.3)$ & $8(66.7)$ \\
\hline Amoxicillin & $8(4.7)$ & $2(25)$ & $6(75)$ \\
\hline Cefuroxime & $2(1.2)$ & $2(100)$ & - \\
\hline Moxifloxacin & $1(0.6)$ & - & $1(100)$ \\
\hline Clarithromycin & $1(0.6)$ & - & $1(100)$ \\
\hline ACE inhibitor/ARA-II & $7(4.1)$ & $6(85.7)$ & $1(14.3)$ \\
\hline Enalapril & $3(1.8)$ & $2(66.6)$ & $1(33.3)$ \\
\hline Lisinopril & $2(1.2)$ & $2(100)$ & - \\
\hline Valsartan & $1(0.6)$ & $1(100)$ & - \\
\hline Olmesartan & $1(0.6)$ & $1(100)$ & - \\
\hline Medical conditions & $32(18.7)$ & $28(87.5)$ & $4(12.5)$ \\
\hline Heavy episodic & & & \\
\hline drinking & $16(9.4)$ & $16(100)$ & - \\
\hline $\begin{array}{l}\text { Upper respiratory } \\
\text { tract infection }\end{array}$ & $7(4.1)$ & $7(100)$ & - \\
\hline Cancer & $3(1.8)$ & $2(66.6)$ & $1(33.3)$ \\
\hline Breast & $2(1.2)$ & $1(50)$ & $1(50)$ \\
\hline Lung & $1(0.6)$ & $1(100)$ & - \\
\hline $\begin{array}{l}\text { Pharyngoesophageal } \\
\text { reflux }\end{array}$ & $2(1.2)$ & $2(100)$ & - \\
\hline Pollen immunotherapy & $1(0.6)$ & - & $1(100)$ \\
\hline Hymenoptera venom & $1(0.6)$ & - & $1(100)$ \\
\hline FXII-HAE & $1(0.6)$ & - & $1(100)$ \\
\hline Tonsillectomy & $1(0.6)$ & $1(100)$ & - \\
\hline Idiopathic & $38(22.2)$ & $28(73.7)$ & $10(26.3)$ \\
\hline
\end{tabular}

Abbreviations: EU, edema of the uvula; NSAID, nonsteroidal antiinflammatory drug; ACE, angiotensin-converting enzyme; ARA-II, angiotensin II receptor antagonist; FXII-HAE, hereditary angioedema with FXII mutation; -, no patients.

An elongated uvula, snoring, obesity, smoking, and OSA have all been reported to be predisposing factors for EU $[1,5,6]$. In fact, elongated uvula - a rare malformation - was seen in 52 of the patients we studied ( 45 isolated EU, 7 nonisolated EU), and in all 52, it rested clearly on the dorsum of the tongue. However, in the present study, smoking and obesity were not linked to EU because there were no significant differences between patients with isolated EU and patients with nonisolated EU. Moreover, interestingly, patients diagnosed with OSA syndrome $(8.8 \%)$ exclusively had isolated EU, although this is difficult to explain.

The 4 major causative groups of EU described to date include food-induced, drug-induced, medical condition-associated, and idiopathic EU [5,20,22]. In the present study, a cause was established for 133 patients; the most common (both for isolated EU and nonisolated EU) was allergy to $A$ simplex ( 35 out of the
Table 4. Statistics for Patients With Isolated EU and Nonisolated EU

\begin{tabular}{lcc} 
Serum Parameters $^{\mathrm{a}}$ & $\begin{array}{c}\text { Isolated EU } \\
(113 \text { Patients })\end{array}$ & $\begin{array}{c}\text { Nonisolated EU } \\
(58 \text { Patients })\end{array}$ \\
\hline Total IgE & $63(38-123.5)$ & $71(42.5-179)$ \\
Baseline tryptase & $3.6(2.65-5.15)$ & $3.4(2.7-4.93)$ \\
C3 & $108(84-127.5)$ & $112(85-125)$ \\
C4 & $26(17-32)$ & $28.5(18-34)$ \\
C1-INH & $28(25.5-30.5)$ & $28(26-30.3)$
\end{tabular}

Abbreviations: EU, edema of the uvula; C1-INH, C1-esterase inhibitor. aTotal IgE, normal to $100 \mathrm{lU} / \mathrm{mL}$; Baseline tryptase, normal to $11.4 \mu \mathrm{g} / \mathrm{L} ; \mathrm{C} 3$, ranged from 75 to $150 \mathrm{mg} / \mathrm{dL} ; \mathrm{C} 4$, ranged from 12 to $40 \mathrm{mg} / \mathrm{dL} ; \mathrm{C} 1-\mathrm{INH}$, ranged from 22 to $34 \mathrm{mg} / \mathrm{dL}$. Data are expressed as median and interquartile range (in brackets).

total 171 patients [20.5\%]). In the largest series of EU patients reported to date, however, such sensitivity was the causal factor in only 1 patient (1.7\%) [5]. The involvement of Anisakis species in the present study may be explained in 2 ways. First, the consumption of uncooked fish is more common in central Spain ( $13.8 \%$ of all fish consumption) than in the area where the abovementioned study was performed, ie, the Mediterranean area of Spain (4.8\%). Consequently, the prevalence of IgE-mediated sensitivity (45.6\% and $27.2 \%$, respectively) and allergy $(23.8 \%$ and $9.8 \%$, respectively) to Anisakis are different in these areas [23]. Furthermore, most fish consumed in central Spain comes from the North Atlantic, where Anisakis-infested fish are more common than in the Mediterranean Sea [24]. Epidemiological findings such as these are important in guiding prevention and treatment. Moreover, these 35 patients had no further episodes of EU when they followed a strict Anisakis avoidance diet during the following years, including 12 Anisakis-allergic patients with nonisolated EU. Daschner et al [22] also reported Anisakis to be the most common cause of EU in the 17 patients they studied. However, these authors could only establish a cause for under one third of patients. They also identified snoring as a predisposing factor, although no observations were made regarding the influence of an elongated uvula.

EU was drug-induced in some study patients. NSAIDs and ACE inhibitors/ARA-II were the cause of $8.8 \%$ and $4.1 \%$ of cases (isolated EU plus nonisolated EU), respectively. These figures are similar to those reported in a series of 58 patients by Alcoceba et al [5] (5.2\% and 3.4\%, respectively). In the present study, allergies to antibiotics (demonstrated by a convincing medical history, skin testing, and, in selected cases, challenge testing) accounted for $7.0 \%$ of all cases of EU (isolated EU plus nonisolated EU) (Table 3). Interestingly, antibiotics have never before been reported to be a cause of EU.

In the present study, heavy episodic drinking and upper respiratory tract infection were the medical conditions most commonly associated with EU (exclusively isolated EU). The reason for this, however, remains unclear. On the other hand, we identified a mutation (Thr318Lys) in the FXII gene along with a normal $\mathrm{C} 1$ inhibitor protein level and normal $\mathrm{C} 1$ inhibitor activity function in the patient diagnosed with FXII-HAE [11]. She was instructed to self-administer icatibant by subcutaneous injection in the abdomen if necessary. We 
highlight 3 cancer patients who had no further EU episodes after receiving adequate antitumor treatment. However, in spite of all the data presented, we had the impression that several factors were needed to produce EU.

Our study is considerably limited by the absence of a healthy control group to identify risk factors for EU (independently of whether this is isolated or not). The study is also limited by regional differences in diet and the prevalence of infection throughout the world. We are also aware of the limitations/shortcomings of Anisakis, which prevent our data from being extrapolated to many other populations. Nevertheless, the strengths of our study include the size of the sample and the length of follow-up (3 years after diagnosis). Taking into account these data in our area, we believe that diagnosis and therapy can be improved by ruling out Anisakis and foods/drugs as causes, visually inspecting the uvula, and determining whether the patient is a snorer (predisposing factor). These 4 factors (Anisakis, foods/drugs, elongated uvula, and snoring) accounted for the vast majority of cases of uvular edema in our study.

In conclusion, the present results suggest snoring, an elongated uvula, and previous EU episodes to be predisposing factors for isolated EU in our study population. Anisakis allergy was the variable most commonly associated with EU. Such knowledge may help in the prevention and management of EU, which can sometimes be a severe condition. However, no medical condition was firmly associated with isolated EU or nonisolated EU, and it seems difficult to act based on such scarce evidence. Further research must be carried out in order to clarify other causes and predisposing factors of EU and the interactions between them.

\section{Acknowledgments}

The authors would like to thank Enrique Fernández-Caldas for critically reviewing the manuscript.

\section{Funding}

This study was partially supported by the Proyecto de Investigación del Instituto de Salud Carlos III, reference PI18/01726 "Estudio del estado de senescencia del sistema inmunoinflamatorio en la lesión medular de larga duración y su relevancia clínica. Análisis de la significación patogénica de la traslocación bacteriana intestinal", and by the Programa de Actividades de $\mathrm{I}+\mathrm{D}$ entre grupos de investigación de la Comunidad de Madrid en Biomedicina, reference B2017/ BMD-3804 "Medicina individualizada traslacional en inflamación y cáncer”.

\section{Conflicts of Interest}

The authors declare they have no conflicts of interest.

\section{Previous Presentation}

Preliminary findings from this study were presented in poster form at the November 2010 Meeting of the Spanish Society of Allergy and Clinical Immunology, Madrid, Spain and in oral form at the October 2014 Meeting of the Spanish Society of Allergy and Clinical Immunology, Salamanca, Spain.

\section{References}

1. Nachman R, Krispin A, Nnoli M, Hiss J. Infantile asphyxia due to aberrant uvula-an anatomic misadventure. J Forensic Leg Med. 2010;17:401-3.

2. Daghistani KJ. Conditions of the uvula: a 14 years experience. Auris Nasus Larynx. 2000;27:261-4.

3. Patel RV, Cho C, Medd C, Cresswell J. Isolated non-hereditary angioneurotic oedema of uvula (Quincke's disease) in an adolescent. BMJ Case Rep. 2014 Apr 9;2014. pii: bcr2013203312.

4. Cevik Y, Vural S, Kavalci C. Isolated uvular angioedema: Quincke's disease. Int J Emerg Med. 2010;3:493-4.

5. Alcoceba E, Gonzalez M, Gaig P, Figuerola E, Auguet T, Olona M. Edema of the uvula: etiology, risk factors, diagnosis, and treatment. J Investig Allergol Clin Immunol. 2010;20:80-3.

6. Kim SY, Kim MH, Cho YJ. Different clinical features of anaphylaxis according to cause and risk factors for severe reactions. Allergol Int. 2018;67:96-102.

7. Heinzerling L, Mari A, Bergmann KC, Bresciani M, Burbach G, Darsow $U$, et al. The skin prick test - European standards. Clin Transl Allergy. 2013;3(1):3.

8. Agache I, Bilò M, Braunstahl GJ, Delgado L, Demoly P, Eigenmann $P_{\text {, et }}$ al. In vivo diagnosis of allergic diseases-allergen provocation tests. Allergy. 2015;70:355-65.

9. Barbarroja-Escudero J, Sanchez-Gonzalez MJ, Antolin-Amerigo D, Rodriguez-Rodriguez M, Alvarez-Mon M. Nonoccupational Airborne-Induced Anaphylaxis Caused by Anisakis simplex. J Investig Allergol Clin Immunol. 2016;26(3):196-7.

10. Brockow K, Garvey LH, Aberer W, Atanaskovic-Markovic M, Barbaud A, Bilo MB, et al; ENDA/EAACl Drug Allergy Interest Group. Skin test concentrations for systemically administered drugs -- an ENDA/EAACI Drug Allergy Interest Group position paper. Allergy. 2013;68:702-12.

11. Cicardi M, Aberer W, Banerji A, Bas M, Bernstein JA, Bork K, et al. Classification, diagnosis, and approach to treatment for angioedema: consensus report from the Hereditary Angioedema International Working Group. Allergy. 2014;69(5):602-16.

12. Mosby's Medical Dictionary, 8th edition. (2009). Retrieved February 18, 2017. http://medical-dictionary.thefreedictionary. com/predisposing+factor and http://medical-dictionary. thefreedictionary.com/etiology

13. Marston L, Carpenter JR, Walters KR, Morris RW, Nazareth I, White IR, et al. Smoker, ex-smoker or non-smoker? The validity of routinely recorded smoking status in UK primary care: a cross-sectional study. BMJ Open. 2014;4:e004958.

14. Gea A, Bes-Rastrollo M, Toledo E, Garcia-Lopez M, Beunza JJ, Estruch R, et al. Mediterranean alcohol-drinking pattern and mortality in the SUN (Seguimiento Universidad de Navarra) Project: a prospective cohort study. $\mathrm{Br}$ J Nutr. 2014;111(10):1871-80.

15. Global Status Report on Alcohol and Health. 2014 ed. World Health Organization. WHO Library Cataloguing-in-Publication Data.

16. Gonzalez-Casanova I, Sarmiento OL, Gazmararian JA, Cunningham SA, Martorell R, Pratt $M$, et al. Comparing three body mass index classification systems to assess overweight and obesity in children and adolescents. Rev Panam Salud Publica. 2013;33(5):349-55. 
17. Epstein LJ, Kristo D, Strollo PJ Jr, Friedman N, Malhotra A, Patil SP, et al. Adult Obstructive Sleep Apnea Task Force of the American Academy of Sleep Medicine. Clinical guideline for the evaluation, management and long-term care of obstructive sleep apnea in adults. J Clin Sleep Med. 2009;5(3):263-76.

18. Deary V, Ellis JG, Wilson JA, Coulter C, Barclay NL. Simple snoring: not quite so simple after all? Sleep Med Rev. 2014; 18(6):453-62.

19. Johansson SG, Bieber T, Dahl R, Friedmann PS, Lanier BQ, Lockey RF, et al. Revised nomenclature for allergy for global use: Report of the Nomenclature Review Committee of the World Allergy Organization, October 2003. J Allergy Clin Immunol. 2004;113(5):832-6.

20. Raux F, Carrat X, Pescio P, Carles D, Devars F, Traissac L. Uvular edema. Diagnostic, etiologic and therapeutic management. Rev Laryngol Otol Rhinol (Bord). 1999;120(2):111-4.

21. Nasr VG, Bitar MA, Chehade JM, Dagher WI, Baraka AS. Postoperative severe uvular edema following tonsillectomy in a child with a history of obstructive sleep apnea. Paediatr Anaesth. 2008;18(7):673-5.

22. Daschner A, Vega F. Uvular angioedema: clinical and etiologic aspects in a series of 17 patients. XXII EAACI Congress. 2004 June 12-16; Madrid, Spain. Amsterdam: Springer; 2004. p. 57-58.

23. Fernández de Corres L, Del Pozo MD, Aizpuru F, Buendía E. Prevalence of sensitisation to Anisakis simplex in three Spanish areas, regarding the rates of fish consumption. Relevance of
Anisakis simplex allergy (Prevalencia de la sensibilización a Anisakis simplex en tres áreas españolas, en relación a las diferentes tasas de consumo de pescado. Relevancia de alergia a Anisakis simplex. Estudio multicéntrico de la SEAIC). Alergol Inmunol Clin. 2001;16:337-46.

24. Adroher FJ, Valero A, Ruiz-Valero J, Iglesias L. Larval anisakids (Nematoda: Ascaridoidea) in horse mackerel (Trachurus trachurus) from the fish market in Granada (Spain). Parasitol Res. 1996;82:253-6.

- Manuscript received July 27, 2018; accepted for publication September 17, 2018.

\section{José Barbarroja-Escudero}

Servicio de Enfermedades del Sistema Inmune-Alergia, Hospital Universitario Príncipe de Asturias

Departamento de Medicina y Especialidades Médicas, Facultad de Medicina y Ciencias de la Salud, Universidad de Alcalá, Alcalá de Henares (Madrid), Spain

Carretera Madrid-Barcelona Km 33.600, 28805 Alcalá de Henares (Madrid), Spain

E-mail:jose.barbarroja@gmal.com;jose.barbarroja@uah.es 